\title{
Insect Diversity and Water Quality Parameters of Two Ponds of Chatla Wetland, Barak Valley, Assam
}

\author{
PINKI PURKAYASTHA and SUSMITA GUPTA*
}

\author{
Department of Ecology and Environmental Science, Assam University, Silchar - 788011 , India.
}

(Received: July 12, 2012; Accepted: September 17, 2012)

\begin{abstract}
An investigation was carried out on two ponds of Chatla floodplain, Barak valley, Assam with special reference to aquatic insects. Pond 1 is purely a fish pond where as pond 2 is a community pond too. Present study revealed the status of water quality and in turn diversity, density, dominance and abundance of aquatic insects in both the ponds. Almost all the physico chemical parameters of both the ponds were found within permissible range for aquatic life .However in pond 2 level of phosphate was found little higher than pond 1 due to release of soaps and detergents by human influence. In both the ponds order Hemiptera showed maximum relative abundance ( $98 \%$ in pond 1 and $94 \%$ in pond 2). The study revealed lower diversity of aquatic insects in pond 2 than that in pond 1.
\end{abstract}

Key words: Chatla floodplain, Pond, Human interference, Water quality, Aquatic insects.

\section{INTRODUCTION}

Among different ecosystems, wetlands constitute one of the most important ecosystems for man offering numerous regulating services. Water quality assessment of small water bodies of the wetlands are of immense importance in the management of fisheries, water supply, and irrigation. Pollution status of water bodies are usually expressed as biological and physico-chemical parameters ${ }^{1}$. Several authors have extensively documented the responses of macro-invertebrates to organic and inorganic pollution ${ }^{2,3}$. Chatla floodplain $\left(24^{\circ} 42^{\prime} 697^{\prime \prime} \mathrm{N}\right.$ and $92^{\circ} 46^{\prime} 264^{\prime \prime}$ E) situated in the south of Silchar town, Barak Valley, Assam has 1500 fishery ponds and 12 seasonal lakes. (Fig.1). Although the wetland is resourceful with variety of macrophytes, trees and fishes it is in a derelict or near derelict state due to high rates of siltation, infestation of weeds, unscientific fishing activities, and use of pesticides in the surrounding tea gardens and agricultural fields ${ }^{4}$ which led to a loss of $73 \%$ wetland area of Chatla floodplain ${ }^{5}$. All these factors can affect the communities of aquatic organisms leading to loss of diversity and species extinction ${ }^{6}$. Since, fluctuations in aquatic insect community can give quick information of their surrounding water quality and are commonly used as tools for marking an integrated assessment of water quality, investigation on water quality of two fishery ponds of Chatla wetland with special reference to aquatic insects was carried out.

\section{MATERIALS AND METHODS}

The topography of the Chatla floodplain is fenland type with small hillocks strewn among large stretches of lowland. Pond 1 is a fish pond and is relatively undisturbed. Pond 2 is a fishery cum community pond. Water and insect samples were collected in replicates from both the sites during 2009-2010. Physico-chemical parameters such as Air temperature (AT), Water temperature (WT), Transparency, pH, Electrical Conductivity (EC), Dissolved oxygen (DO), Free $\mathrm{CO}_{2}$, Total alkalinity (TA), Nitrate $\left(\mathrm{NO}_{3}{ }^{-}\right)$and Phosphate $\left(\mathrm{PO}_{4}{ }^{3-}\right.$ ), Nitrite $\left(\mathrm{NO}_{2}^{-}\right)$, and Ammonium $\left(\mathrm{NH}_{4}{ }^{+}\right)$content of water were analyzed by standard methods ${ }^{7,10}$. The aquatic insects were collected by kick method whereby the vegetation was disturbed and the 
circular net (mesh size $60 \mu \mathrm{m})$ was dragged around the vegetation for one minute ${ }^{11-12}$. They were immediately sorted, preserved in $70 \%$ ethyl alcohol and were later identified using Dewinter advanced stereo zoom microscope with the help of standard keys ${ }^{13-19}$. A number of identified insects were confirmed in the entomological laboratory of Zoological Survey of India. Statistical analyses were done by MS EXCEL 2007; SPSS 15.0 for Windows, Shannon Wiener Index of Diversity $\left(\mathrm{H}^{\prime}\right)$, Evenness Index $\left(\mathrm{J}^{\prime}\right)$ and Berger-Parker Index of Dominance (d) were calculated by Biodiversity professional version 2 for windows.

\section{RESULTS AND DISCUSSION}

Different physico-chemical parameters (AT, WT, Transparency, pH, EC, DO, Free $\mathrm{CO}_{2}, \mathrm{TA}$, $\left.\mathrm{PO}_{4}{ }^{3-}, \mathrm{NO}_{3}-\mathrm{NO}_{2}-\mathrm{NH}_{4}{ }^{+}\right)$in pond 1 and 2 during Post monsoon 2009 to Monsoon 2010 and their mean concentrations are shown in Table 1. Table 2 showed the distribution of aquatic insects in pond 1 and 2 . The significant correlations that exist among environmental variables, diversity and density of insect are shown in Table 3. Fig. 2 showed the relative abundance of aquatic insect orders recorded from pond 1 and pond 2 during the study period. Relative abundance of aquatic insect families and aquatic insect species in pond 1 and 2 are shown in the Fig.3 and Fig.4 respectively. Pattern of variation in the levels of Shannon Weiner Diversity index ( $\left.H^{\prime}\right)$ and Evenness index (J') and Berger-Parker index of Dominance (d) are shown in the Fig.5.The study revealed that in pond 1 and 2 both air and water temperature did not show much variation. In pond $1 \mathrm{DO}, \mathrm{EC}, \mathrm{NH}_{4}$ and $\mathrm{NO}_{3}{ }^{-}$concentration were slightly higher than that of pond 2 while other parameters such as Transparency, Free $\mathrm{CO}_{2}, \mathrm{TA}, \mathrm{pH}$, and $\mathrm{PO}_{4}{ }^{3-}$ concentration were recorded to be higher in pond 2. The solubility and availability of nutrients is affected by oxygen content of water and therefore the productivity of aquatic ecosystems ${ }^{18}$. The range of $\mathrm{DO}$ recorded in the present study is similar to the DO concentration reported in a previous study in the same area ${ }^{21}$. In pond 1 correlation coefficient analyses revealed a significant negative relationship of WT with $\mathrm{pH}$ and DO. Classical negative relationship of WT with DO was also recorded in a previous study on Chatla floodplain ${ }^{22}$ which is attributed to the fact that in lower temperature oxygen carrying capacity of water increases ${ }^{23}$. Negative relationship of DO with Rainfall might be an indication that surface runoff transported sewage, fertilizer etc. into the pond which have lowered DO value by bacterial respiration ${ }^{22}$. EC was found to be higher in pond 1 (4.59ms/ppt \pm 2.93 ) compared to pond 2 ( $3.24 \mathrm{~ms} /$

Table 1: Physico-chemical properties of water of Pond 1 and Pond 2

\begin{tabular}{|c|c|c|c|c|}
\hline \multicolumn{5}{|c|}{ Study Sites } \\
\hline \multirow[b]{2}{*}{ Parameters } & \multicolumn{2}{|c|}{ Pond 1} & \multicolumn{2}{|c|}{ Pond 2} \\
\hline & Range & Mean \pm Std dev. & Range & Mean \pm Std dev. \\
\hline $\mathrm{AT}\left({ }^{\circ} \mathrm{C}\right)$ & $22.6-29.83$ & $25.93 \pm 0.75$ & $22.6-29.3$ & $25.09 \pm 0.88$ \\
\hline $\mathrm{WT}\left({ }^{\circ} \mathrm{C}\right)$ & $23.37-31.5$ & $26.13 \pm 1.40$ & $23-30.5$ & $26.83 \pm 0.75$ \\
\hline Rainfall(cm) & $0-1484.7$ & $551.98 \pm 590.2$ & $0-1484.7$ & $551.98 \pm 590.2$ \\
\hline $\mathrm{pH}$ & $5.24-6.88$ & $6.27 \pm 0.31$ & $6.38-7.8$ & $7.15 \pm 0.52$ \\
\hline $\mathrm{EC}(\mathrm{ms} / \mathrm{ppt})$ & $0.10-3.57$ & $4.59 \pm 2.93$ & $0.09-7.82$ & $3.24 \pm 0.20$ \\
\hline Transparency $(\mathrm{cm})$ & $0-33.67$ & $14.79 \pm 1.60$ & $13.08-24.83$ & $17.19 \pm 2.77$ \\
\hline $\mathrm{DO}\left(\mathrm{mg} \mathrm{l}^{-1}\right)$ & $5.91-10.43$ & $8.84 \pm 0.86$ & $6.77-9.18$ & $7.83 \pm 0.72$ \\
\hline Free $\mathrm{CO}_{2}\left(\mathrm{mg} \mathrm{l}^{-1}\right)$ & $2.31-11.65$ & $8.28 \pm 0.57$ & $8.42-35.60$ & $16.15 \pm 1.60$ \\
\hline $\mathrm{TA}\left(\mathrm{mg} \mathrm{l}^{-1}\right)$ & $11-30.53$ & $19.93 \pm 2.26$ & $10.43-52.37$ & $26.89 \pm 3.49$ \\
\hline $\mathrm{PO}_{4}{ }^{3-}\left(\mathrm{mg} \mathrm{l}^{-1}\right)$ & $0.32-1.88$ & $0.86 \pm 0.27$ & $0.40-2.16$ & $1.25 \pm 0.72$ \\
\hline $\mathrm{NO}_{3}^{-}\left(\mathrm{mg} \mathrm{l}^{-1}\right)$ & $0.14-1.01$ & $0.53 \pm 0.23$ & $0.13-0.66$ & $0.46 \pm 0.19$ \\
\hline $\mathrm{NO}_{2}^{-}\left(\mathrm{mg} \mathrm{l}^{-1}\right)$ & $0.007-0.02$ & $0.01 \pm 0.01$ & $0.01-0.08$ & $0.03 \pm 0.03$ \\
\hline $\mathrm{NH}_{4}^{+}$ & $0.08-0.48$ & $0.30 \pm 0.13$ & $0.07-0.33$ & $0.17 \pm 0.09$ \\
\hline
\end{tabular}


ppt \pm 0.20 ) where it showed significant positive correlation with TA and $\mathrm{NO}_{3}^{-}$. The range of $\mathrm{NO}_{3}^{-}$ between $0.1-3.0 \mathrm{mgl}^{-1}$ is considered favorable for fish productivity ${ }^{25}$. In both the ponds, $\mathrm{NO}_{3}{ }^{-}$ concentration was found within the said range indicating their suitability for fish production. In pond 2 EC showed significant positive correlation with
TA, Free $\mathrm{CO}_{2}$, and DO. Higher free $\mathrm{CO}_{2}$ accompanied by higher TA and higher $\mathrm{pH}$ in pond 2 could be due to external application of lime. It is known that addition of lime increases fish production in soft (low total hardness) waters by stabilizing the $\mathrm{pH}$ of bottom mud and increasing the availability of Phosphorus and Carbon dioxide for

Table 2: Distribution of aquatic insect species in Ponds 1 and 2 of Chatla floodplain during study period

\begin{tabular}{lllll}
\hline Order & Family & Sp. Name & Pond 1 & Pond 2 \\
\hline Hemiptera & Gerridae & Gerris lepcha Distant & + & + \\
& & Limnogonus nitidus Mayr & + & + \\
& & Neogerris parvula Stål & + & - \\
& Mesoveliidae & Mesovelia vittigera Horvath & + & + \\
& Notonectidae & Enithares fusca Brooks & + & + \\
& & Anisops barbata Brooks & + & + \\
Odonata & Coenagrionidae & Enallagma sp. & + & + \\
Diptera & Culicidae & Culex sp. & - & + \\
\hline
\end{tabular}

Table 3: Significant Correlations among environmental variables, diversity and density of aquatic insects for pond 1 and pond 2

\begin{tabular}{|c|c|c|}
\hline Parameters & Pond 1 & Pond 2 \\
\hline WT Vs pH & $-.956\left(^{*}\right)$ & - \\
\hline WTVs DO & $-.989\left(^{*}\right)$ & - \\
\hline $\mathrm{pH}$ Vs DO & $.989\left(^{*}\right)$ & - \\
\hline $\mathrm{pH}$ Vs Rainfall & $-.987\left(^{*}\right)$ & - \\
\hline EC Vs DO & - & $.995\left({ }^{\star \star}\right)$ \\
\hline $\mathrm{EC} \mathrm{Vs}$ Free $\mathrm{CO}_{2}$ & - & $.954\left(^{*}\right)$ \\
\hline EC VsTA & $.970\left(^{*}\right)$ & $.973\left(^{*}\right)$ \\
\hline $\mathrm{EC} \mathrm{Vs} \mathrm{NO}_{3}^{-}$ & $.983\left({ }^{*}\right)$ & - \\
\hline DO Vs Rainfall & $-.961\left(^{*}\right)$ & - \\
\hline DOVsTA & - & $.977\left(^{*}\right)$ \\
\hline Free $\mathrm{CO}_{2}$ Vs Insect Density & - & $.993\left({ }^{\star \star}\right)$ \\
\hline $\mathrm{TA}_{\mathrm{Vs}} \mathrm{NO}_{3}^{-}$ & $.997\left(^{\star \star}\right)$ & - \\
\hline $\mathrm{NO}_{3}-\mathrm{Vs}$ Rainfall & - & $-.993(* *)$ \\
\hline $\mathrm{NO}_{2}^{-} \mathrm{Vs} \mathrm{NH}_{4}^{+}$ & - & $.967\left(^{*}\right)$ \\
\hline $\mathrm{NO}_{2}^{-}$- Vs Rainfall & - & $.960\left(^{\star}\right)$ \\
\hline $\mathrm{PO}_{4}^{3-} \mathrm{Vs} \mathrm{NO}_{2}^{-}$ & $.955\left(^{\star}\right)$ & - \\
\hline $\mathrm{PO}_{4}^{4-} \mathrm{Vs}$ Insect density & $-.984\left(^{\star}\right)$ & - \\
\hline $\mathrm{NO}_{2}^{4}-\mathrm{Vs}$ Insect density & $-.963\left(^{\star}\right)$ & - \\
\hline Transparency Vs Diversity of insects & - & $.977\left(^{*}\right)$ \\
\hline
\end{tabular}

* Correlation is significant at the 0.05 level (2-tailed). ${ }^{* *}$ Correlation is significant at the 0.01 level (2-tailed). 


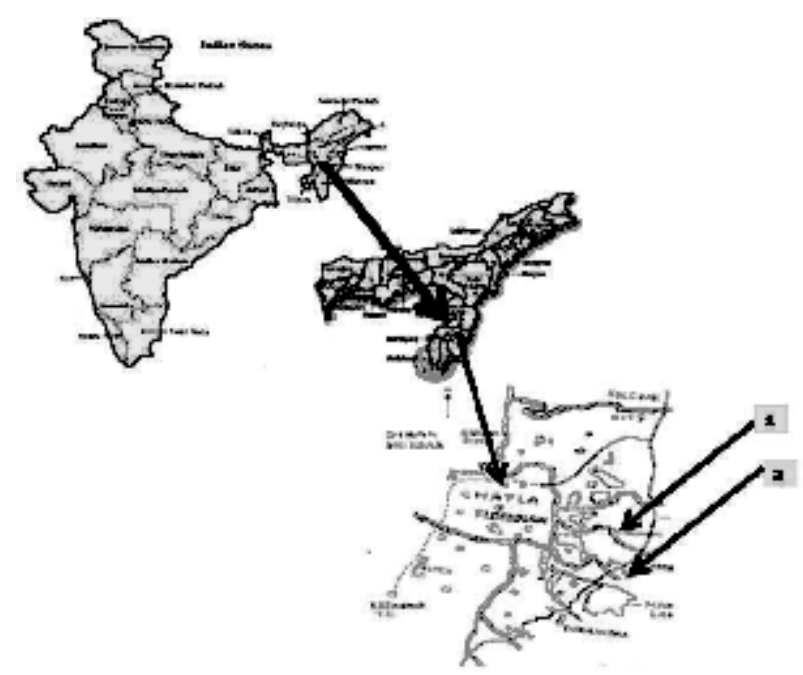

Fig. 1: Location of the two Ponds, 1 and 2 in the floodplain of Chatla Wetland

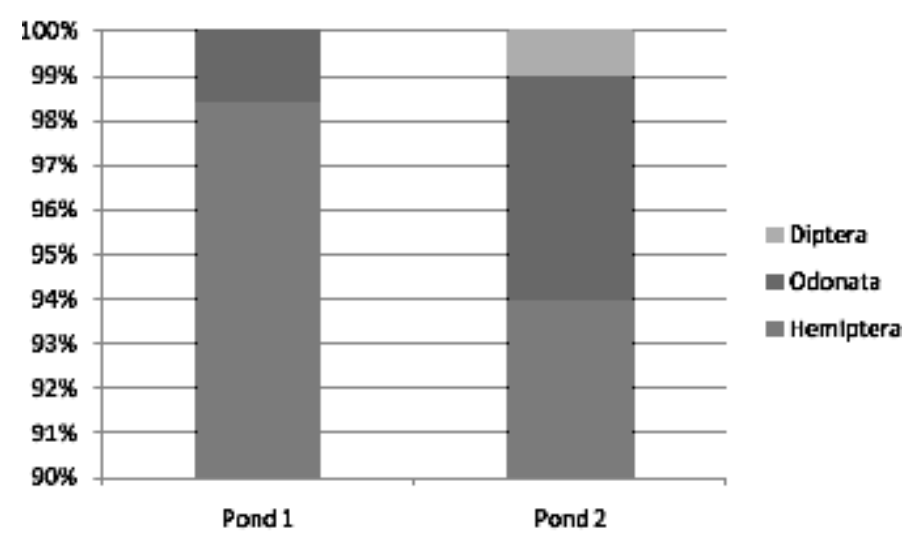

Fig. 2: Relative abundance of insect orders in Pond 1 and Pond 2

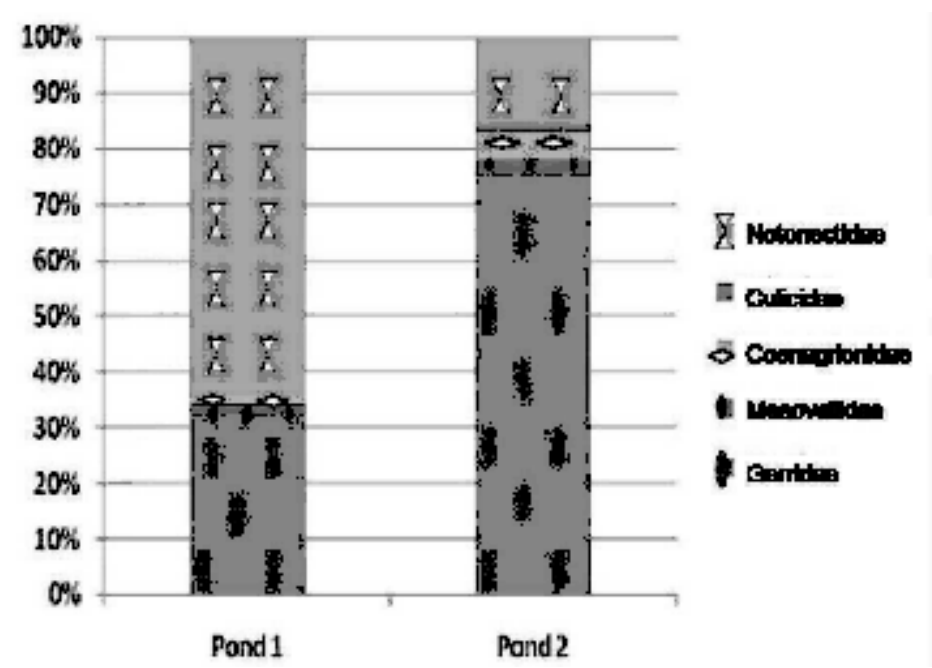

Fig. 3: Relative abundance of aquatic insect families in Pond 1 and Pond 2 
photosynthesis. The overall effect of liming is to increase phytoplankton production which results in increased fish production ${ }^{26}$. Another reason might be that in heavily stocked fish ponds, Carbon dioxide $\left(\mathrm{CO}_{2}\right)$ concentration can become high as a result of respiration. High $\mathrm{CO}_{2}$ concentrations are almost always accompanied by low DO concentrations (high respiration). Acidity of rain water has impact on the $\mathrm{pH}$ of natural water bodies. As rain falls to the earth, each droplet becomes saturated with $\mathrm{CO}_{2}$ and $\mathrm{pH}$ is lowered ${ }^{27}$. This explained the negative relationship of Rainfall with $\mathrm{pH}$ in pond 1 . However in pond 2 no such relationship could be found due to application of lime. In pond 1 DO has shown significant positive correlation with $\mathrm{pH}$, such type of positive correlation in between $\mathrm{DO}$ and $\mathrm{pH}$ have been recorded from the study of Asa lake llorin, Nigeria ${ }^{28}$ where DO distribution followed a similar annual cycle with the $\mathrm{pH}$. In pond 2 DO has shown a positive significant correlation with TA. These alkalinity relationships are extremely important in water

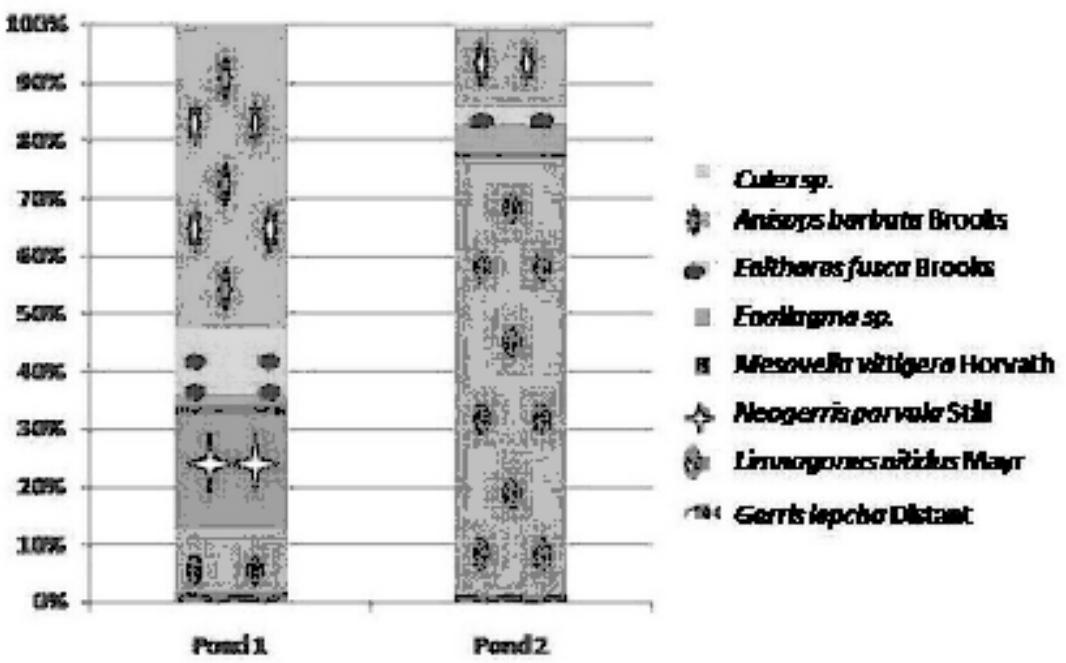

Fig. 4: Relative abundance of aquatic insect species in Pond 1 and Pond 2

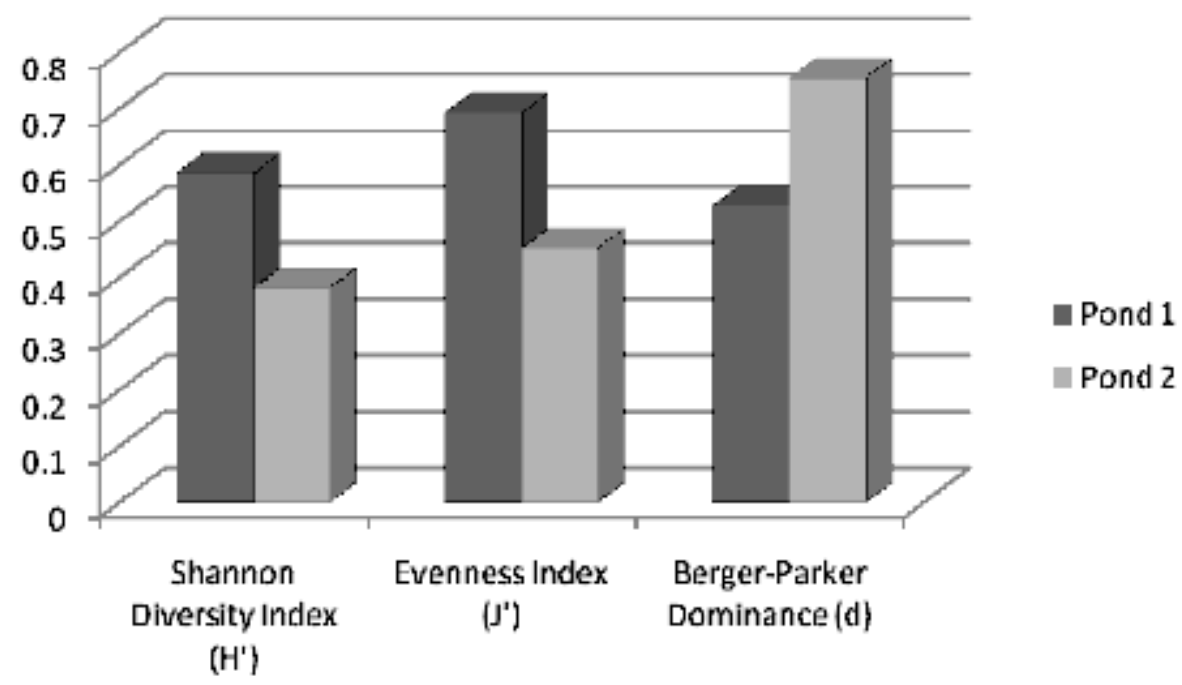

Fig. 5: Pattern of variation in the levels of Shannon diversity index, Evenness index and Berger-Parker dominance of different insect species in both the Ponds 
chemistry, since the most prominent water problems are deposits and corrosion, and these are closely related to the instability of each specific water caused by the tendency of $\mathrm{CaCO}_{3}$ to dissolve in or precipitate from it ${ }^{29}$. Range of $\mathrm{PO}_{4}^{3-}(0.86 \pm 0.27$ in pond 1 and $1.25 \pm 0.72$ in pond 2 ) recorded in the present study is supported by the previous study in a marsh of the same floodplain ${ }^{30}$. Relatively high concentration of $\mathrm{PO}_{4}{ }^{3-}$ in pond 2 might be due to its use as community pond where $\mathrm{PO}_{4}{ }^{3-}$ is contributed by household activities such as washing, bathing etc. In pond $1 \mathrm{PO}_{4}{ }^{3-}$ has shown significant positive correlation with $\mathrm{NO}_{3}$ - Actually large concentration of $\mathrm{PO}_{4}{ }^{3-}$ and $\mathrm{NO}_{3}$ - reported together from a water body indicate that water is eutrophic in nature ${ }^{31}$ but as the water of this pond showed low concentration of both, it indicates the water is not eutrophicated. Rainfall showed significant negative relationship with $\mathrm{NO}_{3}$ - and positive correlation with $\mathrm{NO}_{2}^{-}$in pond 2. A previous study conducted in the same study area also reported relatively high concentration of $\mathrm{NO}_{3}$ during dry months ${ }^{32}$. A positive correlation between $\mathrm{NO}_{2}{ }^{-}$and $\mathrm{NH}_{4}{ }^{+}$is supported by the fact that the most possible way of Nitrate entry in an aquatic system is through oxidation of Ammonia form of Nitrogen to $\mathrm{NO}_{2}^{-}$and to $\mathrm{NO}_{3}$ - consequently ${ }^{31}$.

Aquatic insect community of pond 1 was represented by two orders- Hemiptera, Odonata; four families- Gerridae, Notonectidae, Mesoveliidae (Hemiptera), Coenagrionidae (Odonata) and seven species. Pond 2 was represented by three orders Hemiptera, Odonata, Diptera; five families- Notonectidae, Gerridae, Mesoveliidae (Hemiptera), Coenagrionidae (Odonata); Culicidae (Diptera) and seven species (Table 2). In both the ponds order Hemiptera was the most prominent order, having $98 \%$ relative abundance in pond 1 and $94 \%$ in pond 2 . The most abundant family in Pond 1 is Notonectidae (64\%), followed by Gerridae (32\%), Mesoveliidae ( $2 \%)$, and Coenagrionidae (2\%). In Pond 2 the relative abundance of Gerridae was highest (76\%) followed by Notonectidae (16\%), Coenagrionidae (5\%), Mesoveliidae (2\%) and Culicidae (1\%) (Fig.2 and 3). The aquatic insect species found common in both the ponds were Gerris lepcha Distant, Limnogonus nitidus Mayr, Enithares fusca Brooks, Mesovelia vittigera Horvath, Enallagma sp. and Anisops barbata Brooks. In addition to these species Neogerris parvula Stål was recorded in pond 1 and Culex sp. in pond 2 (Fig.4). Values of Shannon -Weiner Diversity index ( $\left.\mathrm{H}^{\prime}\right)$ and Evenness index (J') were found higher in pond 1 than that of Pond 2 while Berger-Parker index of Dominance (d) value was found higher in pond 2 (Fig. 5). However the $H^{\prime}$ values were found to be less than 1 in both the ponds indicating polluted nature of water ${ }^{35}$. In pond 1 insect density has shown negative correlations with $\mathrm{PO}_{4}{ }^{3-}$ and $\mathrm{NO}_{2}^{-}$ . This might be due to the reason that increased pollution level with high concentration of $\mathrm{PO}_{4}^{3-}$ and $\mathrm{NO}_{2}$-might have disturbed the colonization as many species of aquatic insects are very susceptible to pollution or alteration of their habitat ${ }^{33}$. In pond 2 density of aquatic insects showed positive correlation with Free $\mathrm{CO}_{2}$ which might be due to increased respiration by more number of insects. Rainfall ${ }^{34}$ has shown no significant relationship with diversity or density of aquatic insects in both the ponds. The diversity of aquatic insects showed positive correlation with Transparency. Such kind of positive correlation was reported from lake Victoria ${ }^{37}$. From the study, it can be said that different physico chemical parameters of water quality are inter related and these factors influence diversity, density and distribution of aquatic insects in a particular water body.

\section{ACKNOWLEDGEMENTS}

The authors are thankful to University Grants Commission, New Delhi, India for financial support. Authors are also thankful to the Head, Department of Ecology and Environmental Science, Assam University, Silchar, Assam for providing laboratory facilities. 


\section{REFERENCES}

1. Lenat, D.R., Smock, L.A . and Penrose, D.L., Use of Benthic Macroinvertebrates as Indicators of Environmental Quality, Biological Monitoring for Environmental Effects, Lexinton Books, Toronto, Canada, p-7-114 (1980).

2. Thorne, R.S.T.J. and Williams, W.P. , The response of benthic macroinvertebrates to pollution in developing countries: a multimetric system of bioassessment, Freshwater Biol.,37: 671-686 (1997).

3. Kazanci, N. and Dugel , M., Ordination and classification of macro invertebrates and environmental data of stream in Turkey, Water Sci. Tech., 47: 7-8 (2000).

4. Laskar H. S. and Gupta, S., Chatla Wetland, Cachar, Assam: An ecological appraisal, Northeast Researches, 3(2), 39-48 (2011).

5. Phukon, P. and Laskar, A.A., Wetland Mapping and Change Detection in Part of Barak Valley Using Remote Sensing and GIS, Map India, (2006).

6. Primack, R.B. and Rodrigues, E., Biologia da Conservação, Londrina ( Edited by Viva), p-328 (2001) .

7. Michael, P., Ecological Methods for Field and Laboratory Investigations, Tata Mc. Graw-Hill publishing Company Ltd., New Delhi , p-434 (1984).

8. APHA, Standard methods for the Examination of Water and Wastewater, $19^{\text {th }}$ edition, Published by American Public Health association, 1015, fifteen streets NW Washington, D.C. 20 R.C.0015 ( 2005).

9. K.C. Gupta and J. Oberai, Orient J. Chem., 26(1): 215-221 (2010).

10. A. Malviya, S.K. Diwakar, Sunanda, O.N. Choubey, Orient. J. Chem., 26(1): 319-323 (2010).

11. Brittain, J.E., Studies on the Ientic Ephimeroptera and Plecoptera of Southern Norway, Norskent. Tidsskr , 21, 135-151 (1974).

12. Subramanian, K.A. and Sivaramakrishnan, K.G., Aquatic insects for biomonitoring fresh water ecosystems: A methodology manual, Trust for Ecology and Environment (ATREE),
Bangalore, India, p-31(2007).

13. Kumar, A., Description of the last instar larvae of Odonata from Dehra Dun Valley (India) with notes on biology. I. Suborder Zygoptera, Oriental Insects, 7: 83-118 (1973a).

14. Kumar, A., Description of the last instar larvae of Odonata from Dehra Dun Valley (India) with notes on biology. II. Suborder Anisoptera, Oriental Insects, 7: 291-331(1973b).

15. Thirumalai, G., Aquatic and semi aquatic hemiptera (Insecta) of Javadi Hills, Tamilnadu, Zool. Surv. of India, 18: 63 (1989).

16. Thirumalai, G., Aquatic and semi aquatic hemiptera (Insecta) of Tamilnadu1,Dharampuri and Pudukkatai districts, Zool.Surv.India, Occasion 165: 45 (1994).

17. Bal, A. and Basu, R.C., Insecta: Hemiptera: Mesovellidae, Hydrometridae, Veliidae and Gerridae, In: State fauna series 5, Fauna of West Bengal, India, p-511-534(1994 a).

18. Westfall , M.J. Jr. and Tennessen , K.J., Odonata, In: An introduction to the aquatic insects of North America, (Edited by Merritt, R. W. and Cummins, K. W. ), Dubuque, Kendall Hunt Publishing, IA3,p-164-169 (1996) .

19. ZSI, State fauna series 10. Fauna of Manipur, (Part -2) Insects, Zoological Survey of India, Kolkata, India (2004).

20. Wetzel, R.G., Detrial dissolved and particulate organic carbon functions in aquatic ecosystems, Bulletin of Marine Science, 33: 503-509 (1984).

21. Bhuiyan, J.R. and Gupta, S.A., Comparative Hydrobiological Study of a Few Ponds of Barak Valley, Assam, and Their Role as Sustainable Water Resources, J. Environmental Biol., 28(4): 799-802 (2007).

22. Laskar, H.S. and Gupta, S., Phytoplankton diversity and dynamics of Chatla floodplain lake, Barak Valley, Assam, North East India - A seasonal study, J Environmental Biol. 30(6): 1007-1012 (2009).

23. Wetzel, R.G., Limnology, 2nd edn., Philadelphia :Saunders Coll. Publication, p860 (1983).

24. Singhal, R.N., S, and Davies, R.W. ,The 
physicochemical environment and the plankton of managed ponds in Haryana, India, Proc Ind Acd Ani Sci., 95: 353-364 (1986).

25. Verma, S.K., Fresh water toxic blue-green algal blooms - A response to extra nutrient enrichment, In: Ecology of polluted waters (Edited by Kumar, A.). Voll. II, A.P.H. Publishing Corporation, New Delhi, 11611175 (2002).

26. Lewis, G.W., Pond Fertilization and Liming. Cooperative Extension Service, University of Georgia College of Agricultural \& Environmental Sciences, Athens (1998).

27. William, A.W. and Durborow. , M.R., Interactions of $\mathrm{pH}$, Carbon Dioxide, Alkalinity and Hardness in Fish Ponds, SRAC Publication No. 464 (1992).

28. Araoye, P.A., The seasonal variation of $\mathrm{pH}$ and dissolved oxygen $\left(\mathrm{DO}_{2}\right)$ concentration in Asa lake Ilorin, Nigeria, Int. J. of Physical Sciences, 4(5): 271-274 (2009).

29. www.onlinewatertreatment.com (Technifax).

30. Laskar, H.S. and Gupta, S., Ecology of a marsh in Chatla floodplain, Barak Valley,North-East India, Ecology Environment \& Conserv., 16(3): 333-339
(2010).

31. Ahmad, U., Parveen, S. Khan, A.A., Kabir , H.A., Mola, H.R.A. and Ganai, A.H., Zooplankton population in relation to physico-chemical factors of a sewage fed pond of Aligarh (UP), India, Biology and Med. 3(1): 336-341 (2011).

32. Duttagupta, S., Gupta S. and Gupta, A., Gupta Euglenoid blooms in the floodplain wetlands of Barak Valley, Assam, North Eastern India, J Environmental Biol., 25: 369373 (2004).

33. Rajasegar, M. , Psysico-Chemical Characteristics of the Vellar estuary in relation to shrimp farming, J Environmental Biol., 24, 95-101(2003).

34. Staub, R., Appling, J.W., Hofsteiler, A.M. and Hass, I.J., The effect of industrial wastes of Memphis and Shelby county on primary plankton producers, Bioscience, 20: 905-912 (1970).

35. Voshell, J.R. Jr. ,A Guide to Common Freshwater Invertebrates of North America, McDonald \& Woodward Publishing Company, Granville, Ohio, p-.442 (2002).

36. Cachar College Meteorological Observatory data, Cachar College, Silchar, Assam (Rainfall data) (2009-10). 